glacial origin, but until this can be proved the term tilloid is preferred in the sense of Harland, Herod \& Krinsley (1966, p. 233).

The coarse tilloid, a hard siliceous breccia containing elongated fragments of vein quartz, quartzite, grit, phyllite and other highly indurated sediments, in a pale greygreen siliceous and micaceous matrix, is illustrated in Plate 1. The pebbles, reaching 10 $\mathrm{cm}$ in length, are ill sorted and sub-angular, but have been subjected to recrystallization as well as intense deformation, resulting in their distortion and multiple jointing in the rock. The Warsak tilloids, which are described by Ahmad et al. $(1969, \mathrm{pp}$. 54-5) as metaconglomerates and pebbly quartzites, form part of the Pebbly Quartz-Biotite Schist, the top member of the Lower Series of metasediments. They are associated with orthoquartzite, tourmaline-bearing actinolite-epidote quartzite, mica schist, phyllites and shales, overlying the Phyllites and Marble group, and have been tentatively assigned a Devono-Carboniferous age.

The Warsak occurrence may thus be the most northwesterly of the known subcontinental tillites, extending the line of Himalayan localities more than $200 \mathrm{~km}$ to the West.

\title{
References
}

Ahmad, M., Ali, K. S. S., Khan, B. Shah, M. A. \& Ullah, I. 1969. The geology of the Warsak area, Peshawar, West Pakistan. Geol. Bull. Univ. Peshawar 4, 44-78.

Harland, W. B., Herod, K. N. \& Krinsley, D. H. 1966. The definition and identification of tills and tillites. Earth-Sci. Rev. 2, 225-56.

Powell, D. \& Saxena, M. N. 1971. Tillite horizons in the Chamba Himalayas of Himachal Pradesh, North India. $J l$ geol. Soc. Lond. 127, 595-8.

Department of Mineralogy

D. R. C. KEMPE

British Museum (Natural History)

London SW7 5BD

30th January 1973

\section{Poseidon, Proto-Atlantic and Iapetus}

SIR,--I refer to the recent article in this journal by Harland \& Gayer (1972) in which Wilson's (1966) Palaeozoic Proto-Atlantic Ocean is renamed Iapetus in order to eliminate possible confusion with the initial stages of the present Atlantic Ocean. I would point out that there is, in the literature, at least one name which pre-dates the appellations proposed by Wilson and Harland \& Gayer, viz. Poseidon (Schuchert, 1935). In the absence of any formal rules of the kind which govern the nomenclature of organisms, it would seem advisable in the present case to apply, albeit informally, a 'rule of historical priority' and thereby accord precedence to Schuchert's name.

\section{References}

Harland, W. B. \& Gayer, R. A. 1972. The Arctic Caledonides and earlier Oceans. Geol. Mag. 109, 289-314.

Schuchert, C. 1935. Palaeozoic plankton of North America. Am. J. Sci. 29, 462-4.

Wilson, J. T. 1966. Did the Atlantic close and then re-open? Nature, Lond. 211 (5050), 676-81.

Department of Geology

DAVID SKEVINGTON

University College Galway

Galway

Ireland

30th January 1973 
Geol. Mag. Vol. 110, 1973, Kempe (Corres.), Plate 1, facing page 374.

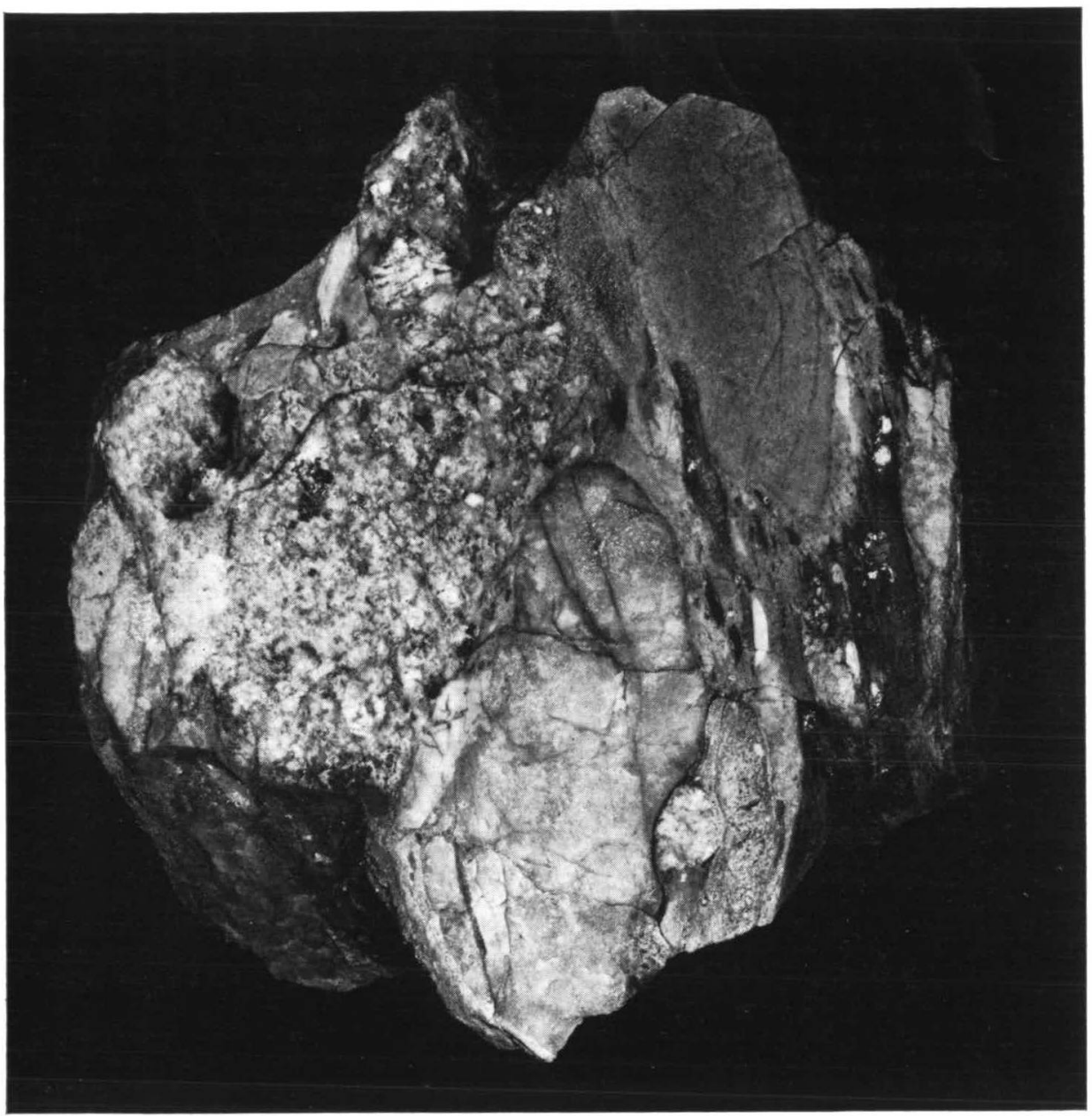

Plate 1. Specimen of the coarse tilloid. The larger clasts include quartzite (left of centre) and vein quartz (bottom centre). The phyllitic material (top right) forms the matrix and consists mainly of quartz and mica. Width of specimen $15 \mathrm{~cm}$. 
SIR,-If we had known about Schuchert's use of Poseidon (ruler of all seas) we should certainly have considered the name carefully before proposing lapetus (father of Atlas or Atlantic) for an earlier generation of (pre-Caledonian and late Precambrian) ocean (1972). Now we have examined the claims of Poseidon we do not consider it appropriate to our concept for the following reasons which may be of general interest. We are grateful to Professor Skevington (above) for causing us to make this enquiry.

Schuchert used the name Poseidon only incidentally in 1935 whilst criticizing Reudemann's interpretation of Ordovician and Silurian black shale assemblages as being of planktonic and sargasso-sea type origin within an ocean. Reudemann (1934) for palaeobiological reasons had argued for an 'Atlantic Ocean' throughout Palaeozoic time where it is now and he incidentally cited this continuing ocean as a major obstacle to the hypothesis of continental drift (pp. 63-4). Therefore, Reudemann's concept of this ocean would not correspond to our concept of Iapetus and he properly used the name Atlantic. Schuchert's criticism was that there was no evidence that the assemblages were generated in a sargasso-sea environment but on the contrary that they originated in continental-shelf and geosynclinal seas and only secondarily drifted into the oceans.

The earliest publications in which we have found Poseidon used by Schuchert both appeared in 1928 where the same map is reproduced and depicts 'Paleogeography of Early Permian time-C. Schuchert 1923'. In this map on a Mercator Projection without any displacement of existing continental outlines Poseidon is the North Atlantic basin north of the land bridge from Gondwana to Amazonia and south of the Eria Baltic land area with greatly reduced sea levels. It connects eastwards into Tethys and westwards through to the Pacific. Nereis was the south Atlantic basin and no name was given to an oceanic embayment extending from the Arctic between Greenland and Spitsbergen to about Jan Mayen. We might comment that our Iapetus had ceased to exist long before Permian time and the part of it that we postulated lay almost entirely north of Permian Poseidon.

In one of the 1928 papers Schuchert was engaged in a massive and detailed refutation of Wegener where he concluded (p. 140) 'The battle over the theory of the permanency of the earth's greater features introduced by James $D$. Dana has been fought and won by Americans long ago. In Europe, however, ... $\therefore$ That was in the same infuential Tulsa Symposium where van der Gracht had (1928, p. 72) introduced the concept (almost of Iapetus and so unequivocally rejected by Schuchert) that 'America might have moved westward faster than Eurasia, opening a Paleozoic Atlantic geosyncline, which was partly closed again during the Caledonian diastrophism .... Nevertheless Schuchert did allow that if Wegener were in some degree correct there would be an early stage of the present North Atlantic referred to by Schuchert as Poseidon. Therefore, Poseidon might appear to be an appropriate name for such early stages of the present North Atlantic for which Proto-Atlantic (already used in another sense by Wilson in 1966) would be a better name.

In the same year Schuchert (1928b, fig. 3 and p. 798) also used the name Poseidon in a biogeographical discussion relating it to Tethys which has little to do with Iapetus.

Schuchert may not have thought so well of Poseidon for it hardly escaped parenthesis and it does not appear east of America in his later paleogeographic maps for example in 1935b, nor in the monumental posthumous publications in 1943 and 1955. He may have realized, as we have discovered, that Poseidon was (like his Roman counterpart Neptune) the ruler of all seas and not at all suitable to distinguish any particular one.

And so, as it appears that in hardly any respect was Poseidon used in the sense of Iapetus, the rules of biological nomenclature if applied would exclude its use for the earlier ocean.

\section{References}

Harland, W. B. \& Gayer, R. A. 1972. The Arctic Caledonides and earlier oceans. Geol. Mag. 109, 289-314.

Reudemann, R. 1934. Paleozoic plankton of North America. Mem. geol. Soc. Am. 2, $141 \mathrm{pp}$. 
Schuchert, C. 1928a. The hypothesis of continental displacement, Theory of Continental Drift, a Symposium pp. 104-44. Tulsa.

1928b. Review of the late Paleozoic formations and faunas, with special reference to the ice-age of Middle Permian time. Bull. geol. Soc. Am. 39, 869-886.

1935a. Palaeozoic plankton of North America. Am. J. Sci. 29, 462-4.

1935b. Antillean-Caribbean Region, Historical Geology of North America, Vol. 1, 811 pp. New York.

1943. Stratigraphy of the Eastern and Central United States, Historical Geology of North America, Vol. 2, 1013 pp. New York.

1955. Atlas of Palaeogeographic maps of North America. New York.

Skevington, D. 1973. Poseidon, Proto-Atlantic and Iapetus. Geol. Mag. 110 (4).

Van Waterschoot van der Gracht, W. A. J. M. 1928. The problem of Continental

Drift. Theory of Continental Drift, a symposium, pp. 1-75, A.A.P.G. Tulsa.

Wilson, J. T. 1966. Did the Atlantic close and then reopen? Nature, Lond. 211, 676-81.

W. B. HARLAND

Department of Geology

Sedgwick Museum

Downing Street

Cambridge

16th March 1973
R. A. GAYER

Department of Geology

University College

Cathays Park

Cardiff 